\title{
Nowotwór nerki u pacjentów ze szpiczakiem plazmocytowym - opis dwóch przypadków i przegląd piśmiennictwa
}

\author{
Renal cell carcinoma in patients with plasma cell myeloma \\ - two case reports and review of literature
}

\begin{abstract}
Agnieszka Ożańska, Marta Sobas, Magdalena Olszewska-Szopa, Tomasz Wróbel
Klinika Hematologii, Nowotworów Krwi i Transplantacji Szpiku, Uniwersytet Medyczny we Wrocławiu
\end{abstract}

\begin{abstract}
Streszczenie
Szpiczak plazmocytowy (PCM) charakteryzuje sie ekspansja nowotworowych komórek plazmatycznych w szpiku. Rak nerkowokomórkowy (RCC) jest rezultatem ztośliwej proliferacji komórek nabtonkowych kanalików proksymalnych nefronu $i$ stanowi 95\% ztośliwych nowotworów nerki. Wspótistnienie PCM i RCC to zjawisko bardzo rzadkie, istnieja jedynie pojedyncze doniesienia na ten temat. W pracy przedstawiono opis dwóch chorych, u których w trakcie terapii PCM wykryto przypadkowo RCC. Radykalna nefrektomia (we wczesnej fazie choroby) umoziliwita catkowite wyleczenie RCC $i$ kontynuacje terapii PCM. Ponadto $w$ artykule omówiono podobne przypadki opisane w literaturze.
\end{abstract}

Słowa kluczowe: szpiczak plazmocytowy, rak nerkowokomórkowy, współwystępowanie nowotworów, interleukina 6

Hematologia 2018; 9, 2: 153-159

\begin{abstract}
Plasma cell myeloma (PCM) is characterized by malignant spreading of monoclonal plasma cells in bone marrow. Renal cell carcinoma $(R C C)$ is a result of neoplastic proliferation of epithelial cells in nephron proximal convoluted tubule and forms $95 \%$ of malignant kidney's neoplasms. There are some reports about coexistence of PCM and RCC but it is a rare phenomenon. We describe two cases of patients in which during the therapy of PCM, RCC was detected accidentally. Radical nephrectomy in early stage of $R C C$ allowed complete recovery and did not interrupt the continuation of PCM's therapy. Additionally, similar cases from literature are discussed.
\end{abstract}

Key words: plasma cell myeloma, renal cell carcinoma, coexistence of neoplasms, interleukin 6

Hematologia 2018; 9, 2: 153-159

\section{Wprowadzenie}

Szpiczak plazmocytowy (PCM, plasma cell myeloma) charakteryzuje się klonalną proliferacją złośliwych plazmocytów, które zazwyczaj produkują białko monoklonalne [1]. W ostatnich latach rokowanie pacjentów z PCM znacząco się poprawiło, zwłaszcza od czasu wprowadzenia leków

Adres do korespondencji: Agnieszka Ożańska, Klinika Hematologii, Nowotworów Krwi i Transplantacji Szpiku, Uniwersytet Medyczny we Wrocławiu, ul. Pasteura 4, 50-367 Wrocław, tel. +48 71784 25 99, faks +48 7178401 12,

e-mail: aozanska@usk.wroc.pl 
immunomodulujących (talidomid, lenalidomid [Len], pomalidomid) i inhibitorów proteasomu (bortezomib, karfilzomib) [2]. Lenalidomid jest strukturalnym i funkcjonalnym analogiem talidomidu o wzmocnionej immunomodulacji i właściwościach antyangiogennych [3, 4]. Lek ten jest dobrze tolerowany i często stosowany w terapii podtrzymującej u chorych na PCM [2].

W literaturze istnieją przypadki współwystępowania $\mathrm{u}$ chorych na PCM innych nowotworów pierwotnych, tj. raka piersi, jelita grubego, płuc, prostaty, pęcherza moczowego [5]. U chorych na PCM w trakcie terapii, na przykład Len, opisano zwiększone ryzyko występowania kolejnego nowotworu hematologicznego, tj. zespołu mielodysplastycznego (MDS, myelodysplastic syndrome), chłoniaka Hodgkina (HL, Hodgkin lymphoma), przewlekłej białaczki limfocytowej (CML, chronic lymphocytic leukemia), ostrej białaczki szpikowej (AML, acute myeloid leukemia), ostrej białaczki limfoblastycznej B-komórkowej (B-ALL, B-cell acute lymphoblastic leukemia) [5-7]. Dokładny wpływ Len na rozwój drugiego pierwotnego nowotworu (SPM, secondary primary malignancy) u chorych na PCM nie jest znany [4].

Rak nerkowokomórkowy (RCC, renal cell carcinoma) jest rezultatem złośliwej proliferacji komórek nabłonkowych kanalików proksymalnych nefronu [5]. Większość przypadków RCC stanowi rak jasnokomórkowy nerki (ccRCC, clear cell RCC), który najczęściej wiąże się $z$ inaktywacją genu supresorowego von Hippel-Lindau. Dochodzi do nadprodukcji czynnika wzrostu śródbłonka naczyniowego (VEGF, vascular endothelial growth fator). Czynnik ten stymuluje angiogeneze, wzrost guza oraz sprzyja tworzeniu przerzutów [3]. Wcześnie wykryty rak nerki może być skutecznie leczony za pomocą radykalnej nefrektomii, jednak u około $1 / 3$ chorych w chwili diagnozy RCC występują przerzuty. Odpowiedź na standardową chemioterapię jest bardzo zła (odpowiedź uzyskuje się u ok. 5\% chorych). Interesujący w kontekście tematu niniejszego opracowania jest fakt, $\dot{z}$ e istnieją doniesienia na temat aktywności przeciwnowotworowej Len u chorych na RCC w zaawansowanej fazie [8].

W artykule opisano 2 przypadki chorych na PCM, u których wykryto nowotwór nerki. Diagnozę RCC postawiono w trakcie przyjmowania przez nich Len, jednak u jednego $z$ chorych krwiomocz występował już przed rozpoczęciem powyższej terapii. Zastosowanie radykalnej nefrektomii we wczesnej fazie choroby zaowocowało całkowitym wyleczeniem RCC, co umożliwiło kontynuację leczenia PCM. W literaturze są opisy innych przypadków współwystępowania PCM i RCC (tab. 1) [5, 9-14].

\section{Opisy przypadków}

\section{Przypadek 1.}

Czterdziestoczteroletnia pacjentka zgłosiła się do poradni przyklinicznej w czerwcu 2011 roku $\mathrm{z}$ powodu anemii i bólu kręgosłupa w odcinku krzyżowo-lędźwiowym trwających od kilku lat. Chora w wywiadzie podawała przebyte patologiczne złamanie trzonu kręgu L2 w lutym 2011 roku. Wówczas na podstawie biopsji masy okolicy trzonu kręgu L2 rozpoznano szpiczaka odosobnionego. W badaniach laboratoryjnych $z$ czerwca 2011 roku stwierdzono następujące odchylenia: stężenie hemoglobiny $11,4 \mathrm{~g} / \mathrm{dl}$, liczba leukocytów 10,92 tys./ $/ \mu 1$, liczba płytek krwi (PLT, platelets) 352 tys. $/ \mu 1$, stężenie kreatyniny $0,78 \mathrm{mg} / \mathrm{dl}$, stężenie albuminy $44,25 \mathrm{~g} / 1$, stężenie wapnia całkowitego $5,08 \mathrm{mEq} / \mathrm{l}$, aktywność dehydrogenazy mleczanowej (LDH, lactate dehydrogenase ) $200 \mathrm{mg} / \mathrm{dl}$, stężenie beta ${ }_{2}$-mikroglobuliny 2,25 mg/l, stosunek łańcuchów kappa/ /lambda w surowicy 1,46 . W surowicy i w moczu nie stwierdzono obecności białka monoklonalnego, a stosunek wolnych łańcuchów lekkich (FLC, free light chain) kappa do lambda był prawidłowy.

Mimo niskiego odsetka plazmocytów w mielogramie $(2 \%)$ trepanobiopsja ujawniła obfity naciek z komórek plazmatycznych, IgG lambda (+), CD138 (+); kariotyp był prawidłowy. Badania radiologiczne (RTG) kości długich i czaszki nie wykazywały zmian, ale w scyntygrafii kości uwidoczniono wyższy wychwyt znacznika w lokalizacji kręgów TH12-L1. Na podstawie powyższych badań u chorej rozpoznano szpiczaka niewydzielającego (IA wg Międzynarodowego Wskaźnika Prognostycznego (ISS, International Staging System), stadium III wg Duriego i Salmona).

Pacjentka początkowo (11 sierpnia-12 października 2011 r.) otrzymała 4 cykle chemioterapii według schematu CTD (cyklofosfamid, talidomid i deksametazon), a następnie - w związku ze złą tolerancją leczenia - talidomid w dawce $100 \mathrm{mg} /$ /dobę. Powyższy schemat zapewnił częściową odpowiedź (PR, partial remission) na leczenie zgodnie $z$ kryteriami IMWG (International Myeloma Working Group). Dodatkowo chora co 28 dni otrzymywała kwas zoledronowy, a na przełomie grudnia 2011 roku i stycznia 2012 roku zastosowano u niej radioterapię na obszar kręgów L1-L3 (30 Gy w 15 frakcjach). Chorej zaproponowano przeprowadzenie procedury przeszczepienia autologicznych krwiotwórczych komórek macierzystych (auto-HSCT, 


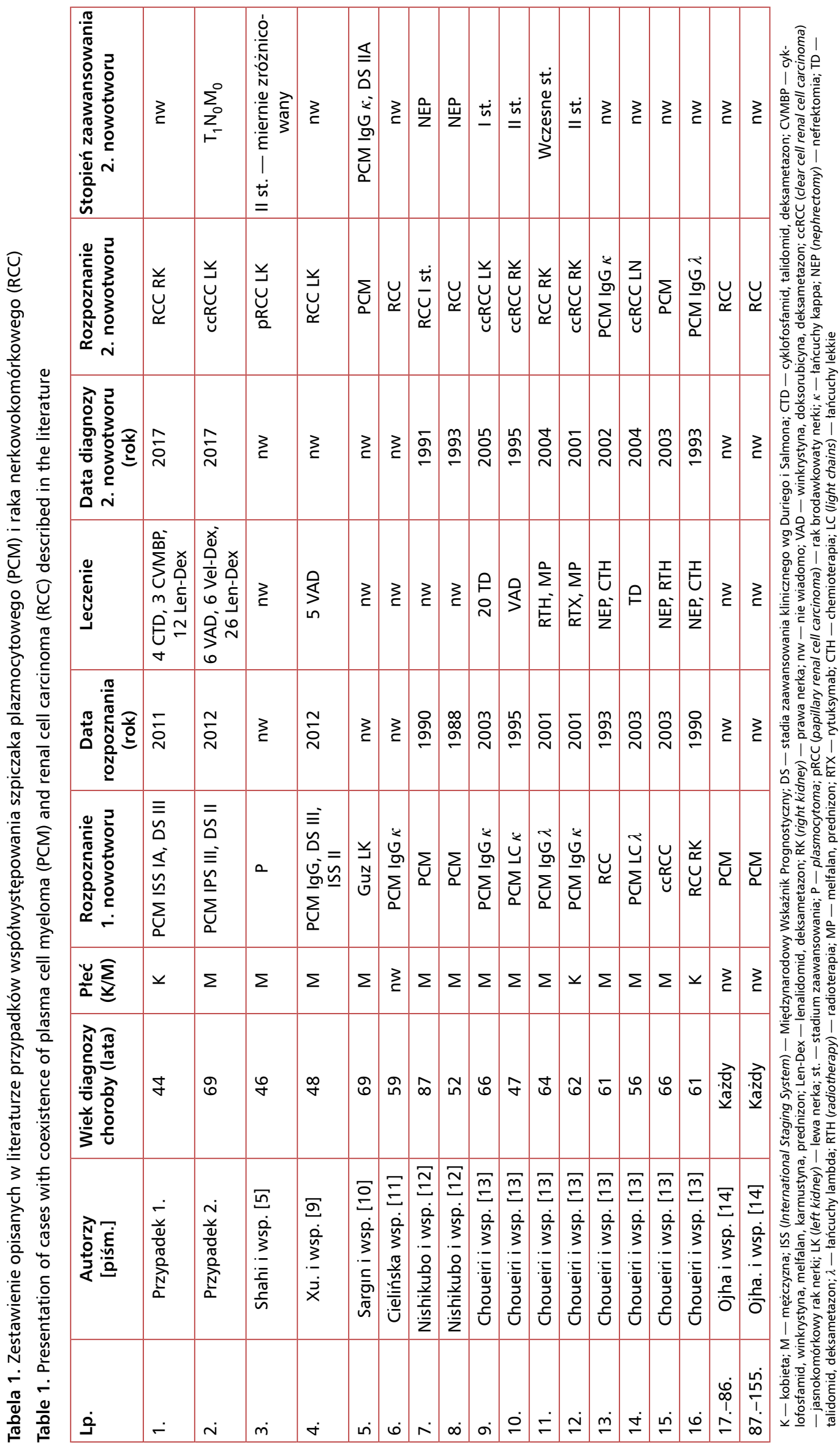


autologous hematopoeietic stem cell transplantation), na którą nie wyraziła zgody. Progresję choroby odnotowano w czerwcu 2012 roku. Chora otrzymała dwa cykle chemioterapii według schematu VMBCP (cyklofosfamid, winkrystyna, melfalan, karmustyna i prednizon) w okresie od czerwca do sierpnia 2012 roku. Leczenie przerwano ze względu na rozpoczynające się objawy neuropatii obwodowej. Uzyskano stabilizację choroby (SD, stable disease) podstawowej zgodnie $z$ kryteriami IMWG. Pacjentka ponownie się nie zgodziła na przeprowadzenie auto-HSCT, w związku z czym w sierpniu 2012 roku została zakwalifikowana do terapii Len-Dex (lenalidomid, deksametazon). $Z$ powodów osobistych chora po otrzymaniu jednego cyklu chemioterapii przestała się pojawiać na wizytach kontrolnych - do grudnia 2015 roku, gdy stwierdzono progresję choroby (nowe ogniska osteolityczne w czaszce, w kręgach L4, L5, TH5, Th11, Th10, kości krzyżowej i obu kościach biodrowych, złamanie kompresyjne kręgów Th5, Th6 oraz Th9). Pacjentkę zakwalifikowano do chemioterapii według schematu VCD (bortezomib, cyklofosfamid, deksametazon). Pacjentka łącznie otrzymała 6 cykli, uzyskując krótkotrwałą SD (zgodnie z IMWG) - w czerwcu 2016 roku potwierdzono progresję choroby podstawowej. Chora ponownie zakwalifikowano do terapii Len-Dex. Odbyła 11 cykli, uzyskując odpowiedź całkowitą (CR, complete response) według IMWG. Równoczasowo przeprowadzono mobilizację komórek CD34 + z myślą o auto-HSCT, na którą tym razem chora wyraziła świadomą zgodę. Niestety, w czerwcu 2017 roku $\mathrm{w}$ rutynowym badaniu ultrasonograficznym jamy brzusznej wykryto guza prawej nerki. Należy zaznaczyć, że u pacjentki przez cały okres choroby parametry funkcji nerek były prawidłowe i nie podawała objawów ze strony nerek. Terapia Len-Dex została przerwana. Chorą poddano zabiegowi operacyjnemu w sierpniu 2017 roku — wynik badania histopatologicznego wykazał RCC. W kwietniu 2018 roku chorą poddano procedurze auto-HSCT.

\section{Przypadek 2.}

Sześćdziesięcioletni pacjent zgłosił się do poradni przyklinicznej w lipcu 2012 roku. Podawał około 6-miesięczny wywiad osłabienia i zmniejszenie masy ciała o około $10 \mathrm{~kg} \mathrm{w}$ poprzedzającym półroczu. W badaniach dodatkowych spośród odchyleń stwierdzono mierną małopłytkowość (liczba PLT 106 tys. $\mu \mathrm{l})$, podwyższone stężenia kreatyniny $(3,95 \mathrm{mg} / \mathrm{dl})$, beta ${ }_{2}$-mikroglobuliny $(8,35 \mathrm{mg} / \mathrm{l})$ i wapnia całkowitego $(6,77 \mathrm{mEq} / \mathrm{l})$. Wartość białka całkowitego wynosiła 74,0 $\mathrm{g} / 1$, a stężenie albuminy
40,18 g/l. Wartości FLC w surowicy były równe: kappa $65200 \mathrm{mg} / 1$, lambda $12,20 \mathrm{mg} / \mathrm{l}$; stosunek FLC kappa/ /lambda wynosił 5344,26. Immunofiksacja surowicy potwierdziła obecność białka monoklonalnego - immunoglobulinowy lańcuch lekki kappa. W RTG czaszki oraz kości długich nie stwierdzono zmian osteolitycznych. Na podstawie powyższych wyników u chorego rozpoznano chorobę łańcuchów lekkich kappa (ISS III, stadium IIB wg Duriego i Salmona).

Chory w okresie od 9 grudnia 2012 roku zrealizował 6 cykli według schematu VAD (winkrystyna, doksorubicyna, deksametazon), uzyskując CR według IMWG. Wartość łańcuchów lekkich kappa w surowicy wynosiła $0,727 \mathrm{~g} / 1$; stężenie łańcuchów lekkich lambda oraz stosunek FLC kappa do lambda były prawidłowe, poziom plazmocytów w szpiku był niższy od 5\%. Od 12 grudnia 2012 roku do 24 stycznia 2014 roku pacjent otrzymywał leczenie podtrzymujące talidomidem w dawce $100 \mathrm{mg} /$ dobę, a następnie co drugi dzień. W marcu 2014 roku chory zaobserwowal krwiomocz, a w badaniach wykazano postępujące narastanie cech niewydolności nerek - wzrost wartości kreatyniny $(2,03 \mathrm{mg} / \mathrm{dl})$ i obniżenie szacunkowego współczynnika filtracji kłębuszkowej ([eGFR, estimated glomerular filtration rate] $32,54 \mathrm{ml} / \mathrm{min} / 1,73 \mathrm{~m}^{3}$ ); stężenie wapnia całkowitego wynosiło 9,5 mg/dl. W czerwcu 2014 roku chorego skierowano na oddział nefrologii w celu przeprowadzenia diagnostyki. Zdiagnozowano prawostronną kamicę moczową i zalecono dalszą obserwację. W marcu 2015 roku stwierdzono progresję szpiczaka według IMWG: FLC kappa osiągnęły wartość $865 \mathrm{mg} / \mathrm{l}$, stężenie FLC lambda było prawidłowe, zaś FLC kappa/lambda wyniósł 60,07 . Chory w okresie od 3 lipca 2015 roku otrzymał 6 cykli bortezomibu $z$ deksametazonem. W lipcu 2015 roku nastąpiła progresja choroby; wartości w surowicy FLC kappa wynosiły $587 \mathrm{mg} / 1$, lambda $31,5 \mathrm{mg} / 1$, a FLC kappa/lambda 18,63. Dodatkowo u pacjenta wystąpiły objawy polineuropatii obwodowej. We wrześniu 2015 roku chory rozpoczął chemioterapię według schematu Len-Dex. Wówczas wartości FLC kappa były podwyższone do $760 \mathrm{mg} / \mathrm{l}$, stężenie FLC lambda pozostawało prawidłowe, a stosunek FLC kappa do lambda wynosił 89,62.

Od grudnia 2015 roku chory ponownie zgłaszał krwiomocz. W tomografii komputerowej (CT, computed tomography) jamy brzusznej ze stycznia 2016 roku w lewej nerce stwierdzono zmianę ogniskową i wymiarach $1,9 \mathrm{~cm} \times 1,7 \mathrm{~cm}$ (początkowo zlecono obserwację). $Z$ powodu małopłytkowości od listopada 2016 roku zmniejszono dawkę Len do $15 \mathrm{mg} /$ /dobę. W kontrolnym rezonansie magnetycznym 
(MRI, magnetic resonance imaging) jamy brzusznej w lutym 2017 roku uwidoczniono masę w lewej nerce $(2,2 \mathrm{~cm} \times 2,1 \mathrm{~cm})$. W sierpniu 2017 roku potwierdzono bardzo dobrą odpowiedź częściową (VGPR, very good partial response) według IMWG — stężenie FLC kappa wynosiło 31,6 mg/l, FLC lambda $-32,7 \mathrm{mg} / \mathrm{l}$, a ich stosunek był prawidłowy. W październiku 2017 roku zadecydowano o przeprowadzeniu resekcji lewej nerki. Na podstawie wyników badań rozpoznano ccRCC w stadium $\mathrm{T}_{1} \mathrm{~N}_{0} \mathrm{M}_{0}$ (5 lat od rozpoznania PCM). Pacjent do tej pory kontynuuje terapię Len (łącznie do tej pory otrzymał 31 cykli). W ostatniej immunofiksacji górną granicę normy przekroczyły tylko wartości FLC kappa (29,5 mg/l), utrzymując SD.

\section{Dyskusja}

Wspólistnienie PCM i innych nowotworów pierwotnych, zarówno hematologicznych, jak i guzów litych, jest opisywane w piśmiennictwie. Zauważono korelację między terapią PCM a zwiększoną częstością innych nowotworów [5]. W ostatniej dekadzie leki o nowym mechanizmie działania (tj. talidomid, bortezomib, Len) poprawiły przeżywalność w szpiczaku. Niedawne doniesienia o wzroście ryzyka zachorowania na drugi nowotwór, głównie na MDS lub ostrą białaczkę w trakcie terapii Len, stanowią kolejne wyzwanie u chorych na PCM [15]. W 2012 roku Agencja ds. Żywności i Leków (FDA, Food and Drug Administration) wydała komunikat o możliwości występowania zwiększonego ryzyka drugich nowotworów pierwotnych, szczególnie AML, MDS oraz HL u chorych na PCM leczonych za pomocą Len. Średni czas od rozpoczęcia terapii Len do zdiagnozowania drugiego pierwotnego nowotworu wynosi 2 lata [7]. Drugi nowotwór pierwotny zdarza się częściej u pacjentów stosujących leki alkilujące lub Len w toku terapii PCM, szczególnie w zaawansowanym wieku. Mimo działań niepożądanych terapii powyższymi lekami korzyści $z$ leczenia przewyższają ryzyko zgonu $z$ powodu drugiego pierwotnego nowotworu [6]. $\mathrm{W}$ badaniu randomizowanym przeprowadzonym przez Jones i wsp. [6] analizowano 2732 chorych na PCM leczonych Len zarówno w indukcji, jak i podtrzymywaniu. Wykryto 104 drugie nowotwory pierwotne u 96 chorych; wykazano wyższe ryzyko zachorowalności $\mathrm{u}$ chorych przyjmujących Len w podtrzymywaniu oraz u chorych po 74. roku życia [6].

Wspólistnienie RCC i PCM jest rzadkim zjawiskiem [16]. Do wspólnych czynników ryzyka zalicza się zarówno cechy kliniczne (otyłość, nadciśnienie tętnicze i palenie tytoniu) [5], jak i genetyczne (ekspresja C-MET [14]). Mutacja onkogenu C-MET została opisana w RCC brodawkowatym [14]. Wpływa ona na proliferację komórek szpiczaka na zasadzie sprzężenia zwrotnego $z$ interleukiną 6 (IL-6) - cytokiną zapalną pełniącą kluczową rolę w rozwoju i wzroście komórek plazmocytów. Cytokiny, a szczególnie IL-6, prawdopodobnie wydzielana przez komórki RCC, mogą stymulować komórki szpiczaka [16]. Interleukina ta jest identyfikowana jako B-komórkowy czynnik różnicowania powodujący proliferację komórek plazmoblastycznych $\mathrm{i}$ indukuje końcowe różnicowanie komórek $\mathrm{B}$ w komórki produkujące przeciwciała [16]. Udowodniono eksperymentalnie, że IL-6 może pełnić rolę autokrynnego czynnika wzrostu u pacjentów z RCC. Ta obserwacja sugeruje, że IL-6 prawdopodobnie uwalniana przez RCC mogłaby się przyczynić do rozwoju lub progresji PCM. Obecność ekspresji $C-M E T$ może stanowić powiązanie przyczynowe między występowaniem obu nowotworów. Czynniki ryzyka związane ze stylem życia, tj. otyłość, wiążą się z liczbą i rozmiarem adipocytów. Tkanka tłuszczowa jest ogromnym źródłem mediatorów zapalnych, szczególnie IL-6 [14, 16].

Ojha i wsp. [14] ocenili dwie kohorty pacjentów w latach 1973-2006 (tab. 1). Byli to pacjenci ze zdiagnozowanym RCC jako pierwotnym nowotworem $(\mathrm{n}=57190)$ oraz chorzy na pierwotnie zdiagnozowanego szpiczaka $(\mathrm{n}=34156)$. W badaniu ujawniono, że u pacjentów $z$ RCC ryzyko zachorowania na PCM było wyższe niż w populacji ogólnej i vice versa. Ryzyko PCM było wyższe o 51\% wśród pacjentów z RCC niż w populacji ogólnej, a relatywne ryzyko RCC było o $89 \%$ wyższe u chorych na PCM niż ryzyko populacyjne. Najwyższe ryzyko RCC obserwowano w pierwszym roku po rozpoznaniu PCM [14].

Dodatkowo II faza badań u pacjentów $z$ przerzutowym RCC była prowadzona w celu określenia bezpieczeństwa i aktywności klinicznej Len. Podawano go w dawce $25 \mathrm{mg} /$ dobę przez $21 \mathrm{dni}$ w 28-dniowych cyklach. Wszystkich pacjentów poddano poprzedzającej nefrektomii, a $57 \%$ otrzymało dodatkowo wcześniejszą terapię. U 10,7\% pacjentów uzyskano PR, u 28,5\% SD, a średni czas wolny od progresji (PFS, progression-free survival) wynosił 4 miesiące. Okazuje się, że Len wykazuje przeciwnowotworowy efekt w przerzutowym RCC, czego dowodem są długotrwałe PR. Trwają dalsze badania w tym zakresie [17].

$\mathrm{W}$ badaniu retrospektywnym, prowadzonym przez Johnson i wsp. [18] przez ponad 3 lata, zidentyfikowano 6 pacjentów ze współwystępującymi RCC i nowotworem hematologicznym; 4 osoby 
spośród tych 6 stosowały terapię immunosupresyjną. Dodatkowo 83\% nowotworów nerek było w I stadium zaawansowania. Brodawkowate raki nerki i ccRCC występowały $z$ tą sama częstością [18]. Rabbani i wsp. [19] opisali 551 przypadków operowanych chorych na RCC $z$ jednego ośrodka w czasie 8 lat. Ich dane ujawnily, że inne nowotwory pierwotne $\mathrm{w} 45 \%$ przypadków są poprzedzone przez RCC. W badaniu populacyjnym przeprowadzonym przez Beisland i wsp. [20] wykazano, że u pacjentów $z$ RCC szacunkowa kumulacja ryzyka rozwoju kolejnego nowotworu w przyszłości wynosi $26,6 \%$ u mężczyzn oraz $15,5 \%$ u kobiet. Zaobserwowali oni, że ryzyko całkowite kolejnych nowotworów u tych pacjentów jest wyższe o $22 \%$ [20]. Znajduje to odzwierciedlenie $\mathrm{w}$ innych danych dostępnych w literaturze, szczególnie w aspekcie chorób limfoproliferacyjnych.

W badaniu III fazy, randomizowanym, kontrolowanym placebo i przeprowadzonym metodą podwójnie ślepej próby, Attal i wsp. [21] oceniali terapię podtrzymującą Len po auto-HSCT szpiku u chorych na PCM. U 614 pacjentów młodszych niż 65 lat, u których nie wystąpiła progresja choroby po pierwszym przeszczepieniu szpiku, utrzymywano terapię Len lub podawanie placebo do czasu nawrotu. Częstość SPM w grupie pacjentów stosującej latami Len wynosiła 3,1 na $100 \mathrm{w}$ porównaniu z 1,2 na 100 pacjentów stosujących przez lata placebo. Najczęstszymi zdarzeniami niepożądanymi w toku terapii Len były powikłania hematologiczne (58\%), które w grupie stosującej placebo stanowiły (22\%). Wyższy wskaźnik zdarzeń kolejnych nowotworów pierwotnych (SPMs) zaobserwowano w grupie leczonej Len. Nowotwór nerki wystąpił u jednego pacjenta $\mathrm{w}$ grupie przyjmującej Len oraz u jednego w grupie stosującej placebo [21].

Należy jednak zaznaczyć, $\dot{z} e-$ zgodnie $z$ literaturą [22] - chorzy na PCM (nawet bez uprzedniego leczenia) oraz $\mathrm{z}$ gammapatią monoklonalną o nieustalonym znaczeniu (MGUS, monoclonal gammopathy of uncertain significance) są obciążeni zwiększonym ryzykiem występowania innych nowotworów. Mailankody i wsp. [22], w badaniu epidemiologicznym opartym na danych ze szwedzkiego rejestru nowotworów (Swedish Cancer Registry), analizowali częstość SPMs u 8740 chorych na PCM i u 5652 pacjentów z MGUS. Szwedzcy chorzy na PCM, w porównaniu ze szwedzką populacją, cechują się 1,26 razy wyższym ryzykiem rozwoju kolejnego nowotworu; u 4,6\% chorych diagnoze SPMs postawiono już $\mathrm{w}$ pierwszym miesiącu od rozpoznania PCM. Ryzyko rozwoju kolejnego nowotworu hematologicznego (głównie AML/MDS) było 2,04 razy wyższe, a niehematologicznego (szczególnie często występowały nowotwory przewodu pokarmowego oraz skóry inne niż czerniak) - 1,19 razy wyższe w PCM. Pacjenci z MGUS $\mathrm{w}$ pierwszym roku od rozpoznania byli obciążeni wyższym ryzykiem drugiego nowotworu, tj. nerki i układu moczowego, układu oddechowego, męskiego układu rozrodczego oraz nowotworów przewodu pokarmowego. W dalszej obserwacji nie stwierdzono predylekcji do konkretnych narządów [22].

W metaanalizie przeprowadzonej przez Palumbo i wsp. [23] porównano występowanie przypadków litych i hematologicznych SPMs u pacjentów $(\mathrm{n}=3254)$ poddawanych i niepoddawanych terapii Len. W trzech badaniach III fazy wykazano wzrost liczby SPMs u pacjentów $z$ nowo zdiagnozowanym PCM, którym podawano Len w podtrzymywaniu po indukcji opartej na melfalanie. Porównano ich z pacjentami, którzy nie otrzymali Len. Zauważono, że pacjenci, którzy stosowali terapię łączoną melfalanem i Len cechowali się wyższym ryzykiem SPMs od chorych, którzy otrzymali sam melfalan. Spośród nowotworów litych częściej obserwowano nowotwory układu moczowego w grupie stosującej Len, prawdopodobnie $z$ powodu wydalania Len przez nerki [23].

\section{Podsumowanie}

Współwystępowanie RCC i PCM jest bardzo rzadkim zjawiskiem. W większości publikacji na ten temat podaje się, że zarówno w przebiegu PCM, jak i RCC częściej zdarzają się kolejne nowotwory. Wydłużenie życia pacjentów ze szpiczakiem, spowodowane postępem w terapii, również zwiększa ryzyko rozwoju kolejnego nowotworu. U chorych na PCM obserwuje się częstsze zachorowania na RCC niż w populacji ogólnej i odwrotnie u pacjentów z RCC notuje się częstszy rozwój PCM w odniesieniu do ryzyka populacyjnego. W obu sytuacjach omówiono wspólne czynniki ryzyka, patogenezę i objawy.

Lenalidomid jest powszechnie stosowany $\mathrm{w}$ terapii $\mathrm{PCM}$, a w fazie badań - równiė w zaawansowanym RCC. Lenalidomid stosowany w populacji chorych na PCM zwiększa ryzyko zachorowania na kolejne nowotwory. Można zatem pośrednio stwierdzić, że terapia Len może się przyczyniać do wystąpienia raka nerki. Jednak fakt, $\dot{z}$ e $z$ powodzeniem wykorzystuje się Len $\mathrm{w}$ terapii RCC, pozwala polemizować $z$ takim założeniem. Na tę chwilę, ze względu na rzadkość występowania zjawiska, brakuje jednoznacznych dowodów na to, że terapia Len zwiększa ryzyko rozwoju RCC. 


\section{Źródła finansowania}

Brak.

\section{Konflikt interesów}

\section{Autorzy deklarują brak konfliktu interesów. \\ Piśmiennictwo}

1. Eslick R, Talaulikar D. Multiple myeloma: from diagnosis to treatment. Aust Fam Physician. 2013; 42(10): 684-688, indexed in Pubmed: 24130968.

2. Pratt G. Lenalidomide and second malignancies in myeloma patients. The Lancet Oncology. 2014; 15(3): 253-254, doi: 10.1016/ /s1470-2045(14)70001-4.

3. Choueiri TK, Dreicer R, Rini BI, et al. Phase II study of lenalidomide in patients with metastatic renal cell carcinoma. Cancer. 2006; 107(11): 2609-2616, doi: 10.1002/cncr.22290, indexed in Pubmed: 17075879.

4. Hutson TE, Sonpavde G, Galsky MD. Targeting growth factor and antiangiogenic pathways in clear-cell renal cell carcinoma: rationale and ongoing trials. Clin Genitourin Cancer. 2006; 5(Suppl 1): S31-S39, indexed in Pubmed: 17239282.

5. Shahi F, Ghalamkari M, Mirzania M, et al. A patient with multiple myeloma and renal cell carcinoma. Int J Hematol Oncol Stem Cell Res. 2016; 10(1): 56-60, indexed in Pubmed: 27047652.

6. Jones JR, Cairns DA, Gregory WM, et al. Second malignancies in the context of lenalidomide treatment: an analysis of 2732 myeloma patients enrolled to the Myeloma XI trial. Blood Cancer J. 2016; 6(12): e506, doi: 10.1038/bcj.2016.114, indexed in Pubmed: 27935580 .

7. Rini B, Redman B, Garcia JA, et al. A phase I/II study of lenalidomide in combination with sunitinib in patients with advanced or metastatic renal cell carcinoma. Ann Oncol. 2014; 25(9): 1794-1799, doi: 10.1093/annonc/mdu212.

8. Thomas A, Mailankody S, Korde N, et al. Second malignancies after multiple myeloma: from 1960s to 2010s. Blood. 2012; 119(12): 2731-2737, doi: 10.1182/blood-2011-12-381426, indexed in Pubmed: 22310913.

9. Xu G, Yang M, Huang J, et al. Coexistence of multiple myeloma and clear cell renal cell carcinoma: a case report and review of literature. Int J Clin Exp Pathol. 2015; 8(6): 7627-7630, indexed in Pubmed: 26261682.

10. Sargin G, Yavasoglu I, Doger FK, et al. A coincidence of renal cell carcinoma and hematological malignancies. Med Oncol. 2012; 29(5): 3335-3338, doi: 10.1007/s12032-012-0316-7, indexed in Pubmed: 22843308.

11. Cielińska S, Urbaniak-Kujda D, Gabryś K, et al. [Coincidence of multiple myeloma and renal clear cell adenocarcinoma].
Pol Arch Med Wewn. 2001; 105(2): 153-156, indexed in Pubmed: 11505750.

12. Nishikubo CY, Kunkel LA, Figlin R, et al. An association between renal cell carcinoma and lymphoid malignancies. Cancer. 1997; 80: 1002-1008.

13. Choueiri TK, Baz RC, McFadden CM, et al. An association between renal cell carcinoma and multiple myeloma: a case series and clinical implications. BJU Int. 2008; 101(6): 712-715, doi: 10.1111/j.1464-410X.2007.07268.x, indexed in Pubmed: 17970789.

14. Ojha RP, Evans EL, Felini MJ, et al. The association between renal cell carcinoma and multiple myeloma: insights from populationbased data. BJU Int. 2011; 108(6): 825-830, doi: 10.1111/j.1464410X.2010.09892.x, indexed in Pubmed: 21091979.

15. US Food and Drug Administration. FDA Drug Safety Communication: Safety review update of cancer drug Revlimid (lenalidomide) and risk of developing new types of malignancies. 2012 [cited 6 March 2018].

16. Ozturk MA, Dane F, Kaygusuz I, et al. Synchronous renal cell carcinoma and multiple myeloma: report of two cases and review of the literature. J BUON. 2009; 14(3): 511-514, indexed in Pubmed: 19810147.

17. Sonpavde G, Hutson TE. Recent advances in the therapy of renal cancer. Expert Opin Biol Ther. 2007; 7(2): 233-242, doi: 10.1517/14712598.7.2.233, indexed in Pubmed: 17250461.

18. Johnson L, Bylund J, Strup S, et al. Concomitant renal cell carcinoma and hematologic malignancy in Immunosuppressed patients. Am J Med Sci. 2016; 351(5): 480-484, doi: 10.1016/j.amjms.2016.02.027, indexed in Pubmed: 27140706.

19. Rabbani F, Grimaldi G, Russo P. Multiple primary malignancies in renal cell carcinoma. J Urol. 1998; 160(4): 1255-1259, doi: 10.1097/00005392-199810000-00012, indexed in Pubmed: 9751330.

20. Beisland C, Talleraas O, Bakke A, et al. Multiple primary malignancies in patients with renal cell carcinoma: a national population-based cohort study. BJU Int. 2006; 97(4): 698-702, doi: 10.1111/j.1464-410X.2006.06004.x, indexed in Pubmed: 16536756.

21. Attal M, Lauwers-Cances V, Marit G, et al. Lenalidomide maintenance after stem-cell transplantation for multiple myeloma. N Engl J Med. 2012(366): 1782-1791, doi: 10.1056/NEJMoa1114138.

22. Mailankody S, Pfeiffer RM, Kristinsson SY, et al. Risk of acute myeloid leukemia and myelodysplastic syndromes after multiple myeloma and its precursor disease (MGUS). Blood. 2011; 118(15): 4086-4092, doi: 10.1182/blood-2011-05-355743, indexed in Pubmed: 21795746.

23. Palumbo A, Bringhen S, Kumar S, et al. Second primary malignancies with lenalidomide therapy for newly diagnosed myeloma: a meta-analysis of individual patient data. Lancet Oncol. 2014; 15(3): 333-342, doi: 10.1016/s1470-2045(13)70609-0. 